Understanding Managed Care 


\section{Understanding \\ Managed Care}

An Introduction for Health Care Professionals

Annette U. Rickel, Washington, D.C.

Thomas N. Wise, Falls Church, V.A.

8 figures in color, 2000

KARGER Basel · Freiburg · Paris · London · New York ·

New Delhi $\cdot$ Bangkok $\cdot$ Singapore $\cdot$ Tokyo $\cdot$ Sydney 


\section{Annette U. Rickel, PhD}

Clinical Professor of Psychiatry

Georgetown University Medical Center, Department of Psychiatry 3800 Reservoir Rd. NW 302A Kober Cogan, Washington, DC 20007, USA

\section{Thomas N. Wise, MD}

Medical Director, Behavioral Health Services

Chairman, Department of Psychiatry, Fairfax Hospital

Professor and Vice Chair, Department of Psychiatry, Georgetown University School of Medicine INOVA Health System, 3300 Gallows Road, Falls Church, VA 22046, USA

Library of Congress Cataloging-in-Publication Data

Rickel, Annette U., 1941-

Understanding managed care: an introduction for health care professionals / Annette U. Rickel,

Thomas N. Wise.

p.; cm.

Includes bibliographical references and index.

ISBN 3-8055-6960-2

1. Managed care plans (Medical care) I. Wise, Thomas N. II. Title.

[DNLM: 1. Managed Care Programs--United States. W 130 AA1 R539u 1999]

RA413.R524 1999

$362.1^{\prime} 04258--\mathrm{dc} 21$

Bibliographic Indices. This publication is listed in bibliographic services, including Current Contents ${ }^{\circledR}$ and Index Medicus.

Drug Dosage. The authors and the publisher have exerted every effort to ensure that drug selection and dosage set forth in this text are in accord with current recommendations and practice at the time of publication. However, in view of ongoing research, changes in government regulations, and the constant flow of information relating to drug therapy and drug reactions, the reader is urged to check the package insert for each drug for any change in indications and dosage and for added warnings and precautions. This is particularly important when the recommended agent is a new and/or infrequently employed drug.

All rights reserved. No part of this publication may be translated into other languages, reproduced or utilized in any form or by any means electronic or mechanical, including photocopying, recording, microcopying, or by any information storage and retrieval system, without permission in writing from the publisher.

${ }^{\circ}$ Copyright 2000 by S. Karger AG, P.O. Box, CH-4009 Basel (Switzerland)

Printed in Switzerland on acid-free paper by Reinhardt Druck, Basel

ISBN 3-8055-6960-2 


\section{Table of Contents}

Introduction $\ldots \ldots \ldots \ldots \ldots \ldots \ldots \ldots \ldots$ VII

1. Historical Perspectives Leading to the Development of Managed Care . . . . . . . . . . . . 1

2. Why Managed Care? . . . . . . . . . . . . . 17

3. Systems of Managed Care . . . . . . . . . 33

4. Components of a Managed Care System . . . . . 53

5. Disease Prevention and Health Promotion . . . . 71

6. New Challenges and Opportunities ... . . . 79

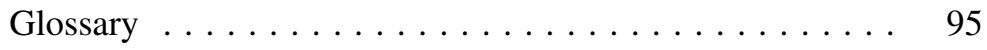

References ........................... 109

Subject Index . . . . . . . . . . . . . . . . . . 117 


\section{Introduction}

This book grew out of our teaching experiences with physicians and allied health care professionals who are graduating with in-depth knowledge of disease states and therapeutics, but little, if any practical knowledge of managed care systems. Managed care is so prevalent that in $1998,85 \%$ of the U.S. working population was in some form of managed care network. Approximately 200,000 physicians are currently enrolled in managed care panels, which represents almost one third of the physicians in practice.

Despite such widespread participation, there has been a significant negative reaction by practitioners who see their autonomy and financial viability threatened. This has led the once conservative American Medical Association to endorse physician's unions to collectively bargain with managed care companies. This decision underscores the discontent that many of the 700,000 physicians in the U.S. have over the direction of the nation's health care system. Such discontent reflects the antagonism between health care professionals and the insurance industry, who paradoxically have been responsible for the economic forces leading to the technological growth of modern medicine.

How much do our students in health care, whether medical students, nurses in training, physical therapists or mental health professionals understand about managed care? Managed care is a broad generic term that encompasses many methods of managing both medical practice and cost. Perhaps there would be less discontent if health care professionals received training during their medical education about the current systems of managed care and methods of providing care within this new milieu. 
A recent Medline search including the years 1990-97 yielded few citations concerning the teaching of the principles of managed care to students in medicine or the allied health care professions. When these students graduate, the managed care environment confronts them with an unknown language, a novel management structure, and an expanding scope of rules and regulations. Finding a job in a desirable location is increasingly difficult, and these new health care professionals are increasingly evaluated on their ability to understand the managed care environment.

This book is designed to serve either as a resource for teaching students or for independent and self-paced study. The initial chapters provide an overview of the changes in health care delivery in the United States, including the forces that are shaping the current environment. The basic structure and components of managed care organizations are then presented as well as the role of managing the health of these organization's populations. In addition, future challenges such as evidence-based medicine, medical ethics and quality measurement are also discussed. A series of cases based on a fictional family selecting a health plan and using its resources are provided to stress important topics; and a glossary section defines basic concepts frequently encountered in the managed care field. Key concepts significant to managed care are emboldened throughout the text and can be found clearly defined in the glossary. Key words are noted in the margins and important information highlighted in the text.

The authors would like to express their appreciation to the W.K. Kellogg Foundation for their support of this project, and to Robert DeVries, our Program Officer for his thoughtful perspective. Geoffry Gabriel's assistance on earlier versions of this manuscript was invaluable and the later work of Evvie Becker and Jody Evans aided in bringing our volume to completion.

We also are grateful for the generous support of the John D. and Catherine T. MacArthur Foundation and particularly thank Robert Rose, Director of Mental Health Policy and Research and Elizabeth McCormack, Vice Chairman of the Board of the Foundation for their guidance.

The MacArthur Foundation awarded us an educational grant to hold a regional training conference on 'Managed Care for New Health Professionals'. This book was used as the basis for the conference and provided an opportunity for us to determine its effectiveness. Presentations were made by Suzanne Gelber, Douglas Kay, Jeanne Matthews and John Wisniewski whose help and encouragement we gratefully acknowledge. From pre to post test, participants 
gained significantly in their knowledge of managed care as well as developed more positive attitudes toward this system of health care delivery.

With a firm and solid foundation gained from the use of this book, medical students and students in the allied health care professions will be more knowledgeable and comfortable in their role in managed care environments. Furthermore, with increased comfort levels and knowledge, it is believed that satisfaction with managed care will increase and positively effect direct patient care.

Annette U. Rickel and Thomas N. Wise 